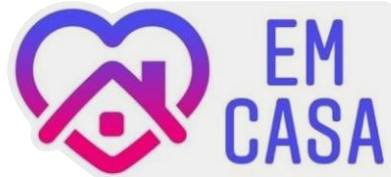

\section{A Morte como Valor Político}

"Toda dor pode ser suportada se sobre ela puder ser contada uma história" Hannah Arendt

Iniciamos esse editorial com essa frase da pensadora Hannah Arendt para dizer que são mais de 150 mil histórias contadas por pessoas que perderam entes queridos/as, vítimas da pandemia no Brasil. Do mesmo modo, muitas histórias estão sendo contadas para perpetuar a presença de jovens negros, negras, pobres, mulheres, LGBTQIA+, assassinados/as nas cidades brasileiras; assim como muitas histórias são cantadas e contadas pelo povo indígena para lembrar as mortes causadas pelo etnocídio do seu povo, vítimas não apenas de pandemias sanitárias, mas da política de morte institucionalizada pela violência do Estado. Vítimas da pandemia e do Estado policial não são estatísticas de uma tragédia, são perdas que afetam pessoas, não são inferências estatísticas.

A dor é um sentimento comum a todas e todos nós, no entanto, a dor é um estado emocional que se revela incomunicável, mesmo que as palavras se encarreguem de traduzi-la, nunca será capaz de expressar sua real intensidade, nunca será fiel em seu propósito de objetivá-la e significá-la. Mas a dor é um estado emocional que, por ser comum a todos/as nós, é capaz de ser compreendida. A dor, seja ela proveniente do sofrimento moral e emocional, ou físico, apesar de incomunicável, ela tem a capacidade de envolver pessoas, de se colocar publicamente provocando reações sem qualquer esforço e iniciativa de quem sofre. Ela é a manifestação de sentimentos e reações diante de uma tragédia, e essa tragicidade possibilita o/a "outro/a" a se identificar com os danos revelados, ou com as histórias contadas, é nesse momento que reconhecemos a nossa humanidade.

O número de mortes, vítimas da pandemia e de mortes decorrente da violência do Estado policial, não são acontecimentos isolados, pelo contrário, fazem parte de uma mesma estratégia do Estado em negar à população socialmente vulnerável o acesso aos direitos básicos, o direito à saúde, à segurança pública, à justiça, enfim, o direito 
à vida. Essa realidade coloca em evidência a suspensão de qualquer sincronia entre a justiça e a vida, e mais, nos faz entender que o conjunto normativo e valorativo, constitutivo do Estado, na verdade, serve para justificar o direito de matar, de atribuir a certos indivíduos a condição de ser supérfluo, descartável e inominável. O Estado, seja ele autoritário, e mesmo democrático, transforma o exercício do poder numa instância seletora da vida e da morte. Mata-se em nome da vida, a vida é retirada sem que essa eliminação se configure em crime. É a condição da "vida nua" do homo sacer, descrita por Giorgio Agamben (2007), do indivíduo que se encontra em tamanho estado de vulnerabilidade que o seu desaparecimento da face da terra nem ao menos venha a se constituir em um fato jurídico. Em situações políticas excepcionais, os indivíduos se encontram incluídos na ordem jurídica unicamente sob a forma de sua exclusão, pois constituem a figura jurídica daquele que podia ser morto por qualquer um, desde que tal morte não seja o resultado de um processo jurídico.

Estamos vivendo em uma necrosociedade que, nesse momento de pandemia sanitária, muda a forma de morrer e "naturaliza" a tragédia, como se tudo estivesse dentro do previsto, afinal, morrer é natural. É a mesma posição diante da "pandemia social”, geradora do ódio pelo/a outro/a, da necessidade do "inimigo". Isso tem levado, cada vez mais, o Estado policial a encerrar vidas e difundir o sentimento de que tudo está sob controle, desde que as mortes façam parte da rotina da cidade.

O Estado, seja em pandemias sanitárias, seja no uso da força policial, funciona como um triturador de corpos. Ele tem a prerrogativa $\mathrm{e}$ o direito de decidir quem morre, quem vive, quem deve ser deixado no corredor da morte nas emergências hospitalares, ou quem deve ser eliminado por ser uma vida fora da contabilidade da ciranda financeira. Estamos vivendo a exacerbação doentia do "fazer morrer, deixar morrer", rotinizando a morte, o que a torna um valor estruturante do poder.

Esse diagnóstico revela que, independentemente de a sociedade ser democrática ou totalitária, o foco é a política da morte, que reproduz a lógica do consumo e da eliminação, descartando o indivíduo que o Estado julga eliminável. É essa descartabilidade e extermínio de pessoas que identificamos o exercício do "necropoder", definido por Achille Mbembe (2018; 2020), como o exercício do poder do Estado de decidir e expor o indivíduo à morte, sem que esse fato demande implicações "fora 
das regras do jogo", e essa eliminação se torna, apenas, meros números estatísticos. O objetivo do Estado, diz Mbembe, é a instrumentalização generalizada da existência humana e a destruição material de corpos humanos, promovendo a suspensão da própria ordem jurídica, que, por meio de tal suspensão, se inclui na exclusão da mesma ordem.

O Brasil vive uma jornada crescente de eliminação e descartabilidade de sua população pobre, negra, indígena, LGBTQIA+. Grande parcela da população tem seu direito à vida negado pelo Estado, que elegeu como regra a matança de pessoas. Entre as mais de 150 mil mortes por COVID-19, a maioria são de negros e pardos, mesmo que a maioria de pacientes hospitalizados seja de pessoas brancas. Do mesmo modo, a porcentagem de óbitos é maior na periferia. São pessoas com menos recursos econômicos e maior dificuldade de chegar à assistência para ter tratamento de boa qualidade. Com a mesma velocidade de prática eliminatória, o alvo maior é a população jovem e negra na periferia, que são mais de $75 \%$ das vítimas de homicídio no país. É conhecido o lugar que o Brasil ocupa nesse ranking, é o país campeão de assassinatos no mundo: em números absolutos, mais de 58 mil pessoas morrem assassinadas por ano. A maioria são jovens entre 15 e 29 anos. Mais triste se torna essa tragédia pela indiferença da sociedade diante de milhares de vidas perdidas. Matar pessoas passou a fazer parte da rotina de um Estado que promove a "naturalização" da indiferença.

A história do país, desde a colonização e escravidão, traz essa marca da história de indivíduos descartados, mortes no atacado, sem nome, sem rosto, mas negros, negras, pobres e escravizados/as. Aqui a morte foi desde cedo, muito mais do que um fato, mas um princípio valorativo promotor de uma escala seletora do direito à vida.

A necropolítica, a política de morte, sustenta-se na dimensão da racialização, que extrapola, na medida em que a condição subalterna reservada aos negros e negras se amplia e se estende como o devir-negro do mundo, sustenta Mbembe. Uma crítica da razão negra, nos termos de Mbembe, é necessária e urgente para eliminar a máquina neoliberal devastadora do capitalismo, que produz indivíduos descartáveis, favelados, migrantes, imprestáveis, toda uma horda de seres matáveis, expostos à morte. É, nesse sentido que Peter Pál Pelbart (2018) destaca, seguindo a Necropolítica de Mbembe, que a política de extermínio revela a sobrevivência da matriz colonial no contexto contemporâneo e, em especial, no Brasil dos dias atuais. Ou seja, a lógica da eliminação colonial se reproduz no presente e se estende aos corpos que o Estado 
considera eliminável. A escravidão continua sendo a matriz que reproduz a relação Estado e sociedade ainda hoje no país.

A revista Cadernos de Gênero e Diversidade nesse número, apresenta um conjunto de temas e análises pertinentes e atuais que, muito mais do que nos levar à reflexões e aguçar o nosso olhar crítico, nos oferece elementos capazes de despertar e vigorar a nossa indignação diante dessa realidade. Com esse propósito, a revista Cadernos de Gênero e Diversidade se coloca como uma ferramenta de luta contra todo tipo de violência e desrespeito à vida, isso pode ser confirmado já nos títulos dos artigos, ensaios, entrevistas, diário de campo, resenha e dossiê, que nos convidam à desobediência ao racismo, à denunciar a recusa ao direito à vida, a entender a política do luto, a denunciar o silenciamento feminino nas esferas do poder político.

Esse número da revista Caderno de Gênero e Diversidade é especial por que, na fala de cada autora e autor, está presente a coragem de contrariar e combater a política da morte, e eleger a vida como valor da resistência. Essa é a luta das Marielles. Viva Marielle Franco, Viva!

\author{
Mariângela Moreira NASCIMENTO \\ Patrícia Rosalba Salvador Moura CosTA \\ Felipe Bruno Martins FERNANDES
}

\title{
Referências
}

AGAMBEN, G. Homo Sacer - o poder soberano e a vida nua. Belo Horizonte, Ed.UFMG,2007.

MBEMBE, A. Crítica da Razão Negra. São Paulo: n-1 edições, 2020. . Necropolítica. São Paulo, São Paulo: n-1 edições, 2018.

PELBART, Peter Pál. Necropolítica Tropical. São Paulo: n-1 Edições, 2019. 